\title{
EFFECT OF SOME NANOBIOSTIMULATORS TO ALLEVIATE THE ADVERSE EFFECTS OF CHILLING STRESS ON TOMATO
}

\author{
A. A. Midan(1), Sally A. Midan(1), Mervat E. Sorial(2), A. G. Zakher(3) \\ and T. W. Nagib(3) \\ (1) Horticulture Dep. Faculty of Agriculture, Minufiya University \\ (2) Botany Dept. Faculty of Agriculture, Minufiya University \\ (3) Horticulture Res. Inst., Agricultural Res. Center, Giza, Egypt.
}

Received: Mar. 8, 2020

Accepted: Jun. 8,2020

ABSTRACT: Two experiments were carried out in private farm (Khatatba Minufiya Governorate) in winter of field 2016/ 2017and 2017/ 2018 seasons to evaluate the alteration of physiological and biochemical processes as well as yield and its quality of tomato plants (Solanum lycopersicum) grown under chilling stress $\left(\left(5-10^{\circ} \mathrm{C}\right.\right.$ at night).

The nanobiostimulators used in this study were, NB compound contains (CPPU, BR and proline) used by two concentrations ( $\mathrm{NB}_{1}: 0.5$ and $\left.\mathrm{NB}_{2}: 1.0 \mathrm{mI} \mathrm{L}\right)$, nano jasmonic acid ( $\mathrm{JA}_{1}$ : 5 and $\left.\mathrm{JA}_{2}: 10 \mathrm{ppm}\right)$, and finally nano silicon $\left(\mathrm{Si}_{1}: 2\right.$ and $\mathrm{Si}_{2}: 3 \mathrm{mM}$ ) beside the control plants which sprayed with tap water. The treatments applied as foliar on tomato seedlings grown under low temperature at 45,60 and 90 day after transplanting.

The results were as following:- low temperature caused significant reductions in plant height, fresh and dry weight of leaves and branches as well as leaf area, chlorophyll content, antioxidant enzymes (PPO, PO and CAT), also reduced proline content and total sugars. Moreover significant reduction in early and total yield and firmness, TSS and Vit $\mathrm{C}$, meanwhile increased chilling injury index $(\mathrm{Cl}) \%$.

Spraying $\mathrm{NB}_{1}$ and $\mathrm{Si}_{1}$ at low concentration caused a significant reduction in chilling injury index $(\mathrm{Cl})$ and increased significantly chlorophyll content, antioxidant enzymes (PPO, PO and CAT), proline content and total sugars. Meanwhile significantly reduced chilling injury index $(\mathrm{Cl})$. Moreover, nanobiodtimulators at low concentration caused a good performance for tomato plants with highly early yield $(57,48 \%)$ and $(43,40 \%)$ for $\mathrm{NB}_{1} \& \mathrm{Si}_{1}$ beside total yield $(30,37 \%)$ and $(20,23 \%)$ for $\mathrm{NB}_{1} \& \mathrm{Si}_{1}$, in both seasons respectively, also the same treatments had induction in firmness, TSS and Vit. C compared to the control plants.

Key words: Chilling, CPPU, BR, JA, Si, proline, Antioxidant enzymes, yield, firmness, vit.c.

\section{INTRODUCTION}

Tomato (Solanum lycopersicum) is one of the most important vegetable crops in Egypt and other world countries for fresh consumption, industry processing and exportation. Moreover, in 2016 total area cultivated by this crop was estimated by 468510 Feddan with a total production of 7727217 tons with an average of 16.49 tons/Feddan*.

Increasing the production and the quality of tomato fruits is very important objective to meet the higher human population demand. Furthermore, it is well known that, a serious reduction in tomato production, in Egypt, was occurred as a result of unfavorable low temperature prevailing during the periods of October, November, December, January and February. Acclimation to cold stress has been reported to involve the synthesis of proteins, membrane lipids, and metabolites that confirm chilling tolerance Graham and Patterson (1982). Yildiztugay et al. (2017) and Hussain et al. (2018) 
reported that chilling stress caused an inhibition in growth of soybean plants.

The mechanism of acclimation has been postulated to involve maintenance of membrane fluidity by increasing lipid unsaturation, and enzymatic protective systems Levitt (1980). More recently, linkage between cold acclimation and resistance to oxidative stress has been postulated Prasad et al. (1994). Thus, oxidative stress plays a dual role lowtemperature response, as a source of injury and as a signal to increase antioxidant defenses. Enhancing cold tolerance was also associated with treatments that increased the level of antioxidants. Evidence has been reported suggesting that cold stress takes the form of oxidative stress, caused by the stimulation of free oxygen radical production Kerdaimongko et al. (1997). In chilling (low temperature) sensitive plants such as Zea mays L., exposure to low temperatures in the light lead to the peroxidation of membrane lipids and the depletion of antioxidant compounds such as tocopherol, both indications of increased levels of reactive oxygen species Prasad et al. (1994). Under severe stress conditions, however, the antioxidant capacity may not be sufficient to minimize the harmful effect of oxidative injury survival under stressful conditions depends on the plant's ability to perceive the stimulus, generate and transmit signals, and induce biochemical changes that adjust the metabolism accordingly.

Nanotechnology opens a large scope of novel application in the field of biotechnology and agricultural industries, because nanoparticles (NPS) have pore size, and particles morphology. Nanoparticles can serve as magic bullets containing herbicides, nano-pesticide fertilizers, or genes, which target specific cellular organelles in plant to release their content.
Researches from their finding suggested both positive and negative effects on plant growth and development, and the impact of engineered nanoparticles (ENPS) on plants depends on the composition, concentration, size and physical and chemical properties of ENPS depend on their concentration and varies from plants to plants $\mathrm{Ma}$ et al. (2010).

CPPU is a member of the synthetic cytokinin group with phenyl urea structure, with strong inhibitory effects on cytokinin oxidation (Mok and Mok, 2001). This synthesis was registered with the trade names of Sitofex and Prestige as a new PGR for grape raisins and kiwifruit in 2005 (Mok and Mok, 2001). These PGRs currently have widespread application in grape raisins and kiwifruit production. The physiological actions of CPPU in plants include increasing fruit size and improving plant fruiting performance by postponing the senescence process (Ahmed and Abdel-aal 2007).

Brassinosteroids (BR) are a group of plant steroid hormones that were first isolated from Brassica pollen about 40 years ago. Around 60 related compounds have been identified $\mathrm{Li}$ et al. (2016). Moreover, BR increase resistance in plants to various kinds of abiotic stress (low and high temperature, drought, heat, salinity, $\mathrm{Ca}(\mathrm{NO} 3)_{2}$, and heavy metal toxicity) (Li et al., 2016) and (Yuan et al., 2012). BR improve the plant defense system to tolerate various stresses by increasing chlorophyll contents, which ultimately increases photosynthetic capacity, enhances antioxidant system capacity, increases enzymatic activity, and up regulates stress response genes [superoxide (SOD), peroxide (POD), catalase (CAT), glutathione physiological and molecular mechanisms of BR under different stress conditions. 
Proline, an amino acid, plays a highly beneficial role in plants exposed to various stress conditions. Besides acting as an excellent osmolyte, proline plays three major roles during stress, i.e., as a metal chelator, an antioxidative defense molecule and a signaling molecule. Review of the literature indicates that a stressful environment results in an overproduction of proline in plants which in turn imparts stress tolerance by maintaining cell turgor or osmotic balance; stabilizing membranes thereby preventing electrolyte leakage; and bringing concentration of reactive oxygen species (ROS) within normal ranges, thus preventing oxidative burst in plants. Reports indicate enhanced stress tolerance when proline is supplied exogenously at low concentration (Hayat et al. 2012).

Jasmonic acid (JA) as an endogenous growth regulator that play an important roles for regulating the stress response (Creelman and Mullet, 1997). The amelioration of chilling injury and osmotic stress by JA have also been reported on rice, peanut seedlings and cucumbers (Wang, 1999). Many researches indicated that JA significantly reduced chilling injury of mango (González-Aguilar et al., 2000), tomato (Ding et al., 2001). Additionally, field applications of JA obviously decrease climacteric ethylene production of peach fruits at harvest by regulating activities of enzymes in cell wall metabolism (Ziosi et al., 2008) and reduce ion leakage in strawberry (González-Aguilar et al., 2006).

Silicon is a beneficial element for cereal and grass. High deposition of $\mathrm{Si}$ in tissues enhances the strength and rigidity of the tissues (Neethirajan et al., 2009). Silicon application enhances water efficiency, chilling and salt tolerance and resistance to pathogens and heavy metals (Guo et al., 2007) and (He et al., 2010).
The present study was undertaken for several objectives:

1- To evaluate the physiological and biochemical impact of low temperature on tomato plants.

2- To investigate the potentialities of nano biostimulators contained CPPU, $\mathrm{BR}$, Proline, also $\mathrm{Si}$ on a number of physiological aspects of tomato plants grown under chilling temperature to determine the extent to whis these nano biostimulators can ameliorate the adverse effects of chilling temperature.

3- To study the physiological behavior and chemical constituents of tomato plants, as well as tomato yield and its quality under these conditions.

\section{MATERIALS AND METHODS}

The present investigation was carried out in private farm of Khatatba Minufiya Governorate during the two successive winter seasons of $(2016,2017)$ and $(2017$, 2018) to investigate, the effect of some nano inducers for induction tomato yield and its quality under this condition.

Tomato seedlings of hybrid $448 F_{1}$ were obtained from Syngenta Company, Egypt, and were transplanted on the $14^{\text {th }}$ and $15^{\text {th }}$ of October in the first and the second seasons, respectively in ridges of $180 \mathrm{~cm}$ apart, in hills, $45 \mathrm{~cm}$ between hills on one side of the ridges.

The experimental units were divided into plots of equal area, each plot was 1.8 $\times 9 \mathrm{~m}=16.2 \mathrm{~m}^{2}$. All the agriculture practices were at the recommendation of Ministry of Agriculture, Egypt.

\section{Treatments:}

Foliar application of different treatments were carried out at 45 days after transplanting and repeated every 15 days intervals, the total number of foliar application reached 3 times. 
A. A. Midan, et al.,

The experiment treatments were designed as a complete randomize design with four replication and included seven treatments which were contain different nano biostimulators as the following:-

1. Control (Tap water).

2. Nano biostimulators ${ }_{1}\left(\mathrm{NB}_{1}\right)(0.5 \mathrm{ml} \backslash \mathrm{L})$

3. Nano biostimulators ${ }_{2}\left(\mathrm{NB}_{2}\right)(1.0 \mathrm{mI} \backslash \mathrm{L})$

4. Nano Jasmonic Acid $\left(\mathrm{JA}_{1}\right)$ ( $\left.5 \mathrm{ppm}\right)$

5. Nano Jasmonic Acid $\left(J_{2}\right)$ (10 ppm)

6. Nano Silicon $\left(\mathrm{Si}_{1}\right)$ (2 $\left.\mathrm{mM}\right)$

7. Nano Silicon $\left(\mathrm{Si}_{2}\right)$ (3 mM)

Nano biostimulator $\left(\mathrm{NB}_{1}, \mathrm{NB}_{2}\right)$ which contains [CPPU $0.2 \%+$ Brassinolide $5 \%$ + proline $1 \%+$ amino oligosaccharin $2 \%]$. This compound (Nano biostimulators ${ }_{1,2}$ ) was obtained from Zhengzhou Zheng Shi Chemical Co., Ltd. China.

Nano Jasmonic Acid $\left(\mathrm{JA}_{1}, \mathrm{JA}_{2}\right)$ was obtained from Prof. Dr. Miersch at Plant Biochemistry. Martin Lather University, D. Giessen, Germany.

Nano Silicon $\left(\mathrm{Si}_{1}, \mathrm{Si}_{2}\right)$ was obtained from Bio Nano Technology Com., Egypt.

Generally, the nanoparticles size less than $50 \mathrm{~nm}$.

\section{Sampling:}

During the growth period of both seasons $(2017,2018)$, three samples were taken randomly from each treatment after 75 days from transplanting. At sampling time, three plants were randomly taken out carefully from each replicate for vegetative growth and chemical analyses.

\section{Data recorded:}

\section{1- Growth parameters}

1.1- Plant height / cm

1.2- Leaves fresh and dry weight $(\mathrm{g})$

1.3- Branches fresh and dry weight (g)

1.4- Total plant fresh and dry weight (leaves+ branches) $(\mathrm{g})$

1.5. Leaf area (LA) $\left(\mathrm{Cm}^{2}\right)$.

1.6. Chilling Injury index $(\mathrm{Cl}) \%$.
In tomato plants, chilling injury manifested as intensity of leaf purpling, therefore, $\mathrm{Cl}$ was scored according to external skin purpling as; minor damage effect (20-25\% purpling lesion, PL); hard damage effect $(>25 \% \mathrm{PL}$ ) and Healthy plants (no symptom). The severity of PL was calculated according to Mirdehghan and Ghotbi (2014) by the following formula:

$\mathrm{Cl}$ index (\%)=

No. of plants at the PL level/plot

Total No. of plants in the treatment/plot

\section{Biochemical parameters:}

\subsection{Chlorophyll content:}

A vegetative samples from the fifth leaf from the growing tip were taken and extracted with $85 \%$ aqueous acetone and determined spectrophotometrically as reported by Wettstein (1957) using the wave length of 662 and $644 \mathrm{~nm}$ for Chl. a and $b$, respectively.

Chlorophyll a conc. $=9.784 \times$ A664 - $0.990 \times$ A647.

Chlorophyll b conc. $=21.426 \times$ A647 - 4.650X A664.

\section{2- Determination of Antioxidant Enzymes Activity:}

2.2.1- Poly Phenol oxidase enzyme activity (PPO): The enzyme activity was measured as the change in the absorbance per minute at $495 \mathrm{~nm}$, and expressed as after $45 \mathrm{~min} / \mathrm{gm}$ Fr.wt. The methods which described by Broesch (1954) were used.

2.2.2 Peroxidase activity (PO): Peroxides activity was measured according to the method described by Fehrman and Dimond (1967). The difference in optical density between the reaction mixture of the activity and that of the control was taken as a measure of the activity of the reaction. Enzyme activity was expressed as OD after $2 \mathrm{~min} / \mathrm{g}$ Fr.wt. 
2.2.3- Catalase activity (CAT): Catalase activity was determined as described by Bach and Oparin (1968).

2.3. Determination of proline content: Proline content was measured by using 5sulphosalysilic acid solvent and acid ninhydrine regent colour intensity was red and measured at $520 \mathrm{~nm}$ using colorimeter according to the method of Bates et al. (1973).

2.4. Total sugars (TS): Total soluble sugars concentration was determined following the method of Dubois et al. (1956).

\section{3- Yield and its components:}

3.1. Fruit set percentage: was measured by randomly chose four plants from each plot and average fruit set of the clusters number 3 and 4 on the main stem was calculated according to the formula:

Fruit set $\%=$

No. of set fruits /cluster

Total No. of formed flowers / cluster

3.2. Early yield: It was considered as the sum of the weight of fruits picked at the first three pickings.

3.3. Total yield: It was determined as the sum of the weight of all harvested fruits that picked at the red ripe stage throughout the entire season.

3.4-Fruit quality: The following fruit qualities were assessed in ten fruits chosen randomly with four replicates/ treatment.

3.4.1. Total soluble solids (TSS): measured by using an Abbe hand refractometer

3.4.2. Fruit firmness: determined in the fruits using pressure tester.

3.4.3. Vitamin C: Vitamin C content was determined in fruit juice using 2, 6dichlorophenolindo-phenol blue dye as $\mathrm{mg}$ ascorbic acid per $100 \mathrm{ml}$ juice,
A.O.A.C. (1980), and expressed as $\mathrm{mg} / 100$ $\mathrm{ml}$ juice.

\section{Statistical analysis:}

The collected data for both years were statistically analyzed using Costat Software (1985) and treatment means were compared by using L.S.D test according to the procedure outlined by Snedecor and Cochran (1972).

\section{RESULTS AND DISSECTION}

\section{1- Growth parameters:}

Effect of chilling stress on tomato growth was studied as influenced by some nanobiostimulators, data recorded in (Table, 1$)$ at two different seasons. As compared to tomato plants, chilling reduced plant height, number of leaves, number of branches, leaves fresh weight, branches fresh weight, leaves and branches dry weight compared to the nanobiostimulators treatments. Significant highest results in the growth parameters recorded with $\mathrm{NB}_{1}$ flowed by $\mathrm{NB}_{2}$ which were best than the chilled plants. $\mathrm{Si}_{1}$ treatment flowed by $\mathrm{Si}_{2}$ were best than the chilled plants only but still lower than $\mathrm{NB}_{1}$ in both seasons.

It can be noticed in (Table, 1 ) that $\mathrm{NB}_{1}$ recorded a highly significant increases in leaves Fr.wt (101\%), total Fr.wt. (222\%) and total Dr.wt. (217\%) compared to its control in the first season, where were $174 \%, 249 \%$ and $265 \%$ when compared to its control in the second season, respectively.

LA of tomato plants was enhanced significantly by treating plants by $\mathrm{NB}_{1}$ under chilling condition. The increases were by $\mathrm{NB}_{1}$ (161\%), Si $i_{1}(122 \%)$ and $\mathrm{JA}_{2}(109 \%)$ when compared with the chilling tomato plants in the first season. Meanwhile the increases in LA by $\mathrm{Si}_{2}(117 \%)$ and $\mathrm{NB}_{2}(94 \%)$ when compared to chilled tomato plants in the first season (Table, 2 and Fig., 1). 
A. A. Midan, et al.,

\begin{tabular}{|c|c|c|c|c|c|c|c|c|}
\hline \multirow{2}{*}{ 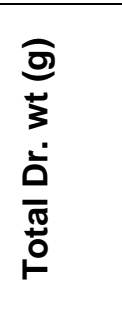 } & $\begin{array}{l}\mathbf{N} \\
\tilde{D} \\
\mathscr{J} \\
\tilde{J} \\
\omega\end{array}$ & $\begin{array}{l}\text { ס) } \\
\text { Ny } \\
\text { ని }\end{array}$ & 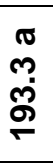 & 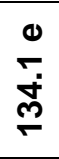 & 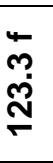 & $\frac{0}{5}$ & 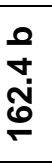 & $\begin{array}{l}0 \\
\frac{0}{0} \\
\stackrel{0}{\sigma}\end{array}$ \\
\hline & 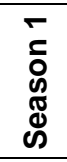 & $\begin{array}{l}0 \\
0 \\
0 \\
6\end{array}$ & \begin{tabular}{l}
$\pi$ \\
\multirow{2}{*}{} \\
\multirow{L}{*}{}
\end{tabular} & $\begin{array}{l}0 \\
0 \\
\dot{J} \\
\tau\end{array}$ & 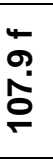 & 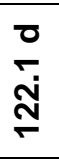 & $\begin{array}{l}0 \\
0 \\
\stackrel{\text { N }}{\text { N }}\end{array}$ & $\begin{array}{l}0 \\
\frac{0}{0} \\
\text { Na }\end{array}$ \\
\hline \multirow{2}{*}{ 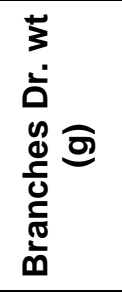 } & 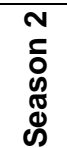 & 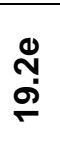 & $\frac{\pi}{\tilde{\sigma}}$ & $\begin{array}{l}\text { ర } \\
\text { ํ. } \\
\text { ల్ల }\end{array}$ & $\frac{\delta}{\check{r}}$ & $\frac{0}{\text { वें }}$ & مَ & 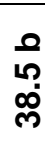 \\
\hline & $\begin{array}{l}\bar{\delta} \\
\bar{\delta} \\
\mathbb{8} \\
\tilde{D} \\
\tilde{D}\end{array}$ & $\begin{array}{l}0 \\
0 \\
\\
\end{array}$ & $\begin{array}{l}\text { đ } \\
\text { ஸุ } \\
\text { \& }\end{array}$ & $\begin{array}{l}0 \\
\circ \\
\text { Iิ }\end{array}$ & $\begin{array}{l}\leftarrow \\
\stackrel{\leftarrow}{N} \\
\text { N }\end{array}$ & 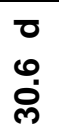 & $\begin{array}{l}\text { م } \\
\text { స్ల }\end{array}$ & $\begin{array}{l}0 \\
\bar{m}\end{array}$ \\
\hline \multirow{2}{*}{ 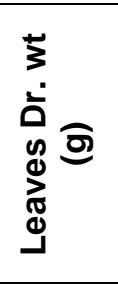 } & 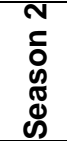 & $\begin{array}{l}\text { ర) } \\
\text { ஜூ }\end{array}$ & 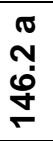 & $\frac{0}{\text { तิ }}$ & $\begin{array}{c}\text { స̃ } \\
\text { ชิ }\end{array}$ & 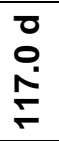 & $\begin{array}{l}\text { Oे } \\
\text { N̦} \\
\text { N̦}\end{array}$ & $\begin{array}{l}0 \\
\stackrel{0}{0} \\
\stackrel{0}{\sigma}\end{array}$ \\
\hline & 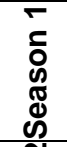 & $\begin{array}{l}0 \\
8 \\
0 \\
0 \\
\end{array}$ & 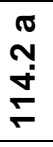 & $\begin{array}{l}0 \\
8 \\
0 \\
10 \\
\infty\end{array}$ & 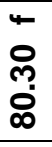 & $\begin{array}{l}\text { ర } \\
0 \\
10 \\
\sigma \\
\end{array}$ & 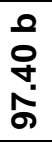 & $\begin{array}{l}0 \\
8 \\
\circ \\
\circ\end{array}$ \\
\hline \multirow{2}{*}{ 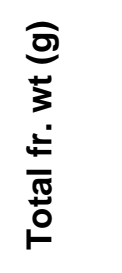 } & 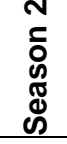 & $\begin{array}{l}\text { ర) } \\
\text { \& }\end{array}$ & $\underset{\infty}{\underset{\infty}{+}}$ & $\begin{array}{l}0 \\
\stackrel{্}{+}\end{array}$ & ড্ল & 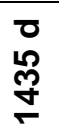 & 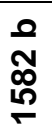 & $\begin{array}{l}0 \\
\text { No } \\
\text { م⿱ }\end{array}$ \\
\hline & 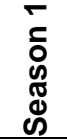 & రి & 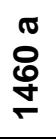 & $\begin{array}{l}\text { ¿ } \\
\text { స్ } \\
\text { }\end{array}$ & $\underset{\frac{5}{5}}{\frac{5}{7}}$ & $\begin{array}{l}\text { ㅇ } \\
\text { مٌ } \\
\stackrel{N}{N}\end{array}$ & 오 & $\begin{array}{l}0 \\
\text { o } \\
\stackrel{\text { N }}{\tau}\end{array}$ \\
\hline \multirow{2}{*}{ 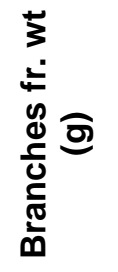 } & 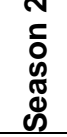 & $\begin{array}{l}\text { ర } \\
\text { ○्ల్ }\end{array}$ & 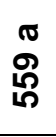 & $\begin{array}{l}0 \\
\text { \& }\end{array}$ & $\begin{array}{l}0 \\
\mathscr{\rho} \\
\mathscr{\rho}\end{array}$ & 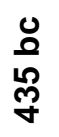 & $\stackrel{0}{\mathcal{Z}}$ & $\begin{array}{l}0 \\
8 \\
8\end{array}$ \\
\hline & 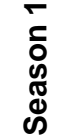 & $\begin{array}{l}\text { ర } \\
\text { ஸે } \\
\Gamma\end{array}$ & $\begin{array}{l}\pi \\
\frac{0}{\sigma}\end{array}$ & $\begin{array}{l}0 \\
\text { ㅇల }\end{array}$ & $\begin{array}{l}0 \\
\text { fै }\end{array}$ & $\begin{array}{l}0 \\
\text { R } \\
\text { R }\end{array}$ & $\begin{array}{l}\text { م } \\
\text { \&্ల }\end{array}$ & $\begin{array}{l}\text { م } \\
\text { \&্ } \\
\text { }\end{array}$ \\
\hline \multirow{2}{*}{ 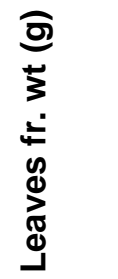 } & 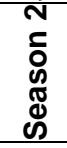 & $\begin{array}{l}0 \\
\frac{0}{6}\end{array}$ & 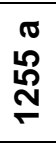 & $\begin{array}{l}0 \\
8 \\
\end{array}$ & $\begin{array}{l}0 \\
\text { ட̊ } \\
\text { \% }\end{array}$ & $\begin{array}{l}0 \\
8 \\
8\end{array}$ & 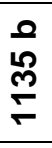 & $\begin{array}{l}\stackrel{0}{\Omega} \\
\approx\end{array}$ \\
\hline & $\begin{array}{l}\bar{c} \\
\overline{0} \\
\tilde{g} \\
\tilde{D} \\
\omega\end{array}$ & $\begin{array}{l}0 \\
8 \\
\circ\end{array}$ & $\begin{array}{l}\text { ர } \\
\text { 옹 } \\
\text { 웅 }\end{array}$ & $\underset{\infty}{\text { D }}$ & $\begin{array}{l}\text { ర } \\
\text { ৪ }\end{array}$ & $\begin{array}{l}0 \\
12 \\
\infty\end{array}$ & $\begin{array}{l}0 \\
\frac{0}{0} \\
\frac{10}{\sigma}\end{array}$ & $\begin{array}{l}0 \\
\text { ৪ }\end{array}$ \\
\hline \multirow{2}{*}{ 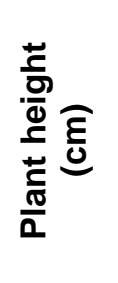 } & $\begin{array}{l}N \\
\tilde{D} \\
\delta \\
\mathbb{8} \\
\tilde{N}\end{array}$ & $\overleftarrow{\widetilde{\sigma}}$ & $\begin{array}{l}\text { ర } \\
\stackrel{\infty}{\infty}\end{array}$ & $\begin{array}{l}\text { ర } \\
\text { م }\end{array}$ & $\begin{array}{l}\mathbf{N} \\
\mathbf{N}\end{array}$ & $\begin{array}{l}\text { ס } \\
\text { م }\end{array}$ & م & $\begin{array}{l}0 \\
0\end{array}$ \\
\hline & 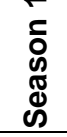 & $\frac{0}{50}$ & $\begin{array}{l}\sigma \\
\infty \\
\infty\end{array}$ & $\begin{array}{l}0 \\
\Re\end{array}$ & $\begin{array}{l}\text { O } \\
\text { R }\end{array}$ & $\begin{array}{l}0 \\
\Re\end{array}$ & $\begin{array}{l}0 \\
\text { N }\end{array}$ & $\begin{array}{l}0 \\
\Re\end{array}$ \\
\hline \multicolumn{2}{|c|}{ 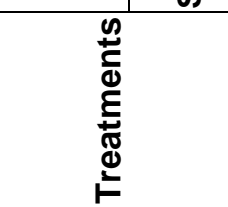 } & $\vec{\delta}$ & $\overline{\mathbf{z}}$ & $\underline{\mathbf{m}}$ & 3 & 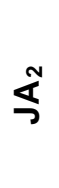 & ๘ & ऊ \\
\hline
\end{tabular}


Table (2): Effect of some nanobiostimulators on leaf area and chilling injury (Cl) percentage of tomato plants grown under low temperature condition (season1: 2016/2017 and season 2: 2017/2018).

\begin{tabular}{|c|c|c|c|c|c|c|}
\hline \multirow{2}{*}{ Treatments } & \multicolumn{2}{|c|}{ LA cm$^{2}$} & \multicolumn{2}{c|}{ Season1 } & \multicolumn{2}{c|}{ Season2 } \\
\cline { 2 - 7 } & Season1 & Season2 & $\mathrm{Cl} \%$ & $\begin{array}{c}\text { Healthy } \\
\text { plants\% }\end{array}$ & $\mathrm{Cl} \%$ & $\begin{array}{l}\text { Healthy } \\
\text { plants\% }\end{array}$ \\
\hline Cont. & $556.4 \mathrm{~g}$ & $762.0 \mathrm{~g}$ & $65 \mathrm{a}$ & $35 \mathrm{f}$ & $60 \mathrm{a}$ & $40 \mathrm{e}$ \\
\hline $\mathrm{NB}_{1}$ & $1450.3 \mathrm{a}$ & $1768.3 \mathrm{a}$ & $10 \mathrm{f}$ & $90 \mathrm{a}$ & $10 \mathrm{e}$ & $90 \mathrm{a}$ \\
\hline $\mathrm{NB}_{2}$ & $1079.5 \mathrm{e}$ & $1296.7 \mathrm{e}$ & $60 \mathrm{~b}$ & $40 \mathrm{e}$ & $55 \mathrm{~b}$ & $45 \mathrm{~d}$ \\
\hline $\mathrm{JA}_{1}$ & $1019.8 \mathrm{f}$ & $1115.2 \mathrm{f}$ & $60 \mathrm{~b}$ & $40 \mathrm{e}$ & $55 \mathrm{~b}$ & $45 \mathrm{~d}$ \\
\hline $\mathrm{JA}_{2}$ & $1162.1 \mathrm{~d}$ & $1415.1 \mathrm{~d}$ & $30 \mathrm{c}$ & $70 \mathrm{~d}$ & $25 \mathrm{c}$ & $75 \mathrm{c}$ \\
\hline $\mathrm{Si}_{1}$ & $1237.0 \mathrm{~b}$ & $1479.2 \mathrm{~b}$ & $15 \mathrm{e}$ & $85 \mathrm{~b}$ & $15 \mathrm{~d}$ & $85 \mathrm{~b}$ \\
\hline $\mathrm{Si}_{2}$ & $1206.5 \mathrm{c}$ & $1446.6 \mathrm{c}$ & $20 \mathrm{~d}$ & $80 \mathrm{c}$ & $15 \mathrm{~d}$ & $85 \mathrm{~b}$ \\
\hline
\end{tabular}
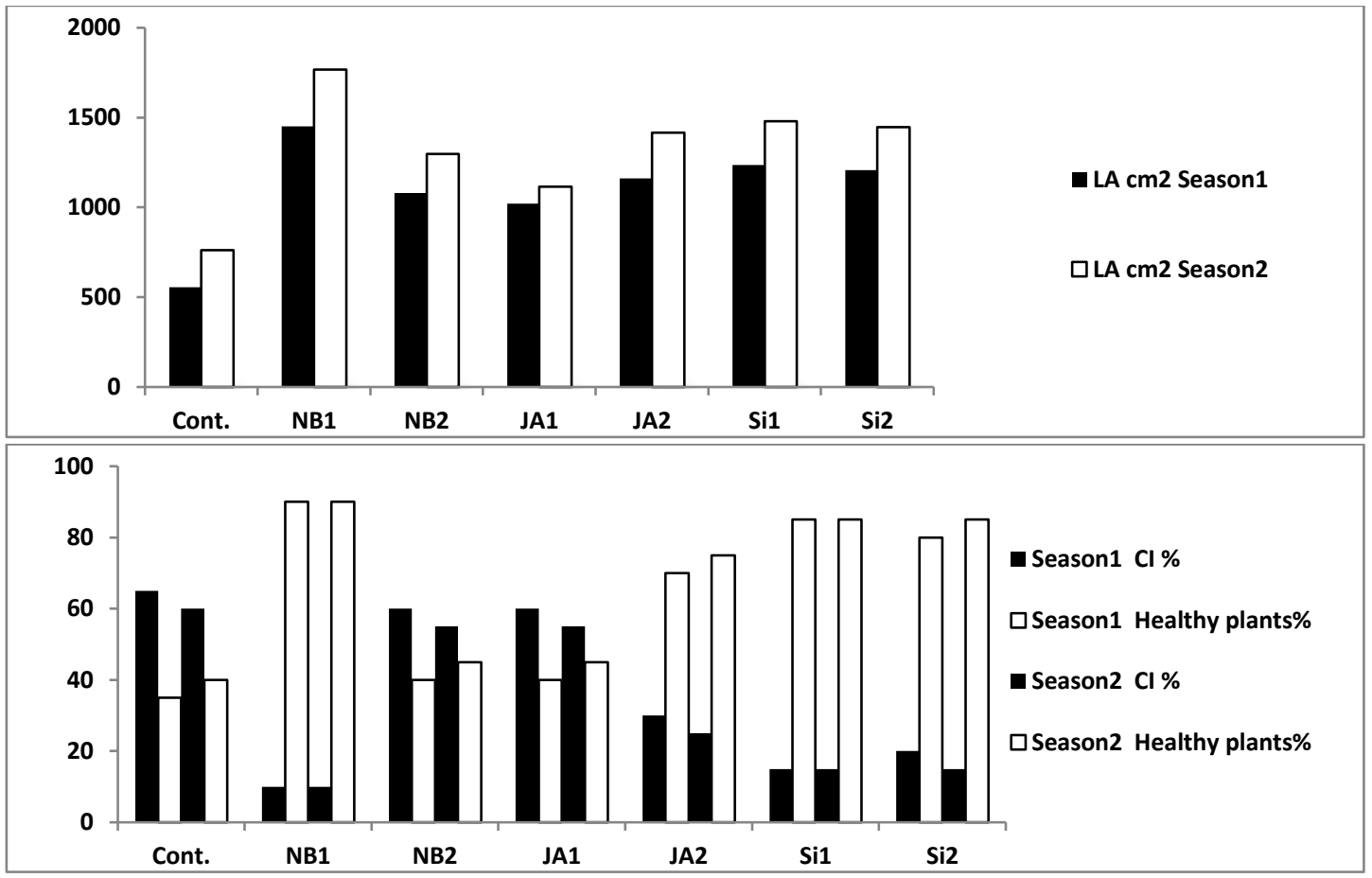

Figure (1): Effect of some nanobiostimulators on leaf area and chilling injury percentage of tomato plants grown under low temperature condition (season1: 2016/2017 and season2: 2017/2018).

Results in the present work indicated that chilling stress had a clear negative impact on various vegetative growth criteria such as: shoot length, fresh and dry weight, leaf area of tomato plants
(Tables 1, 2). Chilling also, resulted in appearance of necrotic spots, burning of margins, wilting and deformation of leaves. In the present investigation data of chilling injury index $(\mathrm{Cl})$ which was scored 
according to external skin purpling as minor and hand effects comparing healthy plants, the data recorded in (Table, 2) illustrated that chilling injury was maximum value in chilled plants $(65 \%$ and $60 \%$ in the first and the second seasons, respectively). The lowest chilling injury index record by treating tomato plants by $\mathrm{NB}_{1}$, and $\mathrm{Si}_{1,2}(10 \%, 15 \%, 30 \%)$ compared to untreated plants in the first season. This result might be due to the effect of CPPU, BR, Si and JA which significantly effective in increasing shoot growth compared the control plants (chilled plants).

Several investigators observed that cold stress induced several morphological symptoms such as a necrosis, desiccation, tissue break-down and wilting (Solank and Sharma 2008), reduced leaf expansion and growth retardation (Rymen et al. 2007) in different plant species such as $P$. vulgaris, Brassica napus, Zea mays and mangosteen tree (Rymen et al., 2007 and Rejab et al., 2008).

Generally, exposure to cold temperature affects crop growth and development through enhancing the production of ROS leading to progressive damage, cell death and growth suppression (Ruiz-Lozano et al. 2012). Also the decreases in vegetative growth and dry matter could be attributed to the inhibition of the main physiological processes and reducing the uptake of nutrients and water (Thakur and Nayyar 2013).

Upon spraying of tomato seedlings grown at low temperature (chilling) by $\mathrm{NB}_{1}$ (Table, 1) improved the growth criteria by increasing shoot length, leaf expansion, fresh and dry weights. Similar results were obtained by Anwar et al. (2018) who mentioned that brassinolides are a group of phytohormones that regulate a wide range of biological processes that lead to tolerance of various stresses by alteration the negative effect of low temperature and chilling stress by increasing chlorophyll contents, carbohydrates which inducing changes in defense enzymes (Mo et al., 2016) and Shu et al., 2016). Brassinolides alleviate the adverse effect of different stress conditions and regulate the defense system by regulating the defense genes in cucumber (Li et al., 2013). Wang and Zeng (1993) reported that brassinolides were shown to have positive effects on eggplant, cucumber and maize under chilling stress, also proline which plays a highly beneficial role as an osmolyte, and helps to stabilize subcellular structures and acts as a metal chelator. Proline (presented in $\mathrm{NB}_{1}, \mathrm{NB}_{2}$ ) may also activate the cellular antioxidant system and scavenge the reactive oxygen species (ROS) (Zouari et al. 2019).

Nimbolkar et al. (2016) found that spraying plants by CPPU at $10 \mathrm{ppm}$ was found most effective in significantly increasing in shoot growth compared to the control pear plants, meanwhile CPPU at $5 \mathrm{ppm}$ recorded a maximum increase in number of leaves, leaf area. Morover ELShraiy Amal and Hegazi Amira (2010) cited that application of CPPU (10 and 20 ppm) showed an improvement in plant growth as indicated by plant height, leaves number, branches number, plant fresh and dry weights.

Sorial Mervat et al. (2010) reported that foliar application of JA at 2.4 and $4.8 \mathrm{mM}$ under water stress decreased plant height and leaf area, whereas increased dry weight of leaves and stems, the highest JA concentration was more effective in this respect. Abd-Alla et al. (2016) proved that application of $\mathrm{MJ}$ to chilled stressed faba bean resulted in enhanced growth and hence biomass accumulation there by depicting the active involvement of JA in cell division and hence organ differention.

These nanostimulatores recorded a maximum increase in number of leaves, leaf area and regulate the defense system 
by regulating morphological, physiological and biochemical characteristics which alleviate the negative effects of low temperature and chilling stress by enhancing chlorophyll content, carbohydrates which inducing changes in defense enzymes (Shu et al., 2016; Anwar et al., 2018; Li et al., 2013 and Nimbolkar et al., 2016)

\section{Biochemical Parameter:}

\subsection{Chlorophyll Content:}

In the present investigation data of chlorophyll content were recorded in (Table, 3), it was observed that there was a significant reduction in chlorophyll (a+ b) content of chilled stress tomato leaves. Plants treated with $\mathrm{NB}_{1}$ and $\mathrm{Si}_{1,2}$ showed significant increase compared to chilled plants, meanwhile JA treatments under studying were less than $\mathrm{NB}_{1}, \mathrm{Si}_{1,2}$ and more than chilled plants. The same trend was observed in the both seasons.

Low temperature (chilling stress) inhibits the photosynthesis of plants by affecting chlorophyll components. Yildiztugay et al. (2017) cited that low temperature (chilling) reduced photosynthetic activity. The decrease in chlorophyll under chilling stress is mainly as a result of damage to chlorophyll caused by active oxygen species (ROS). However, under chilling stress conditions there will be degradation in pigment compositions, which induce decrease in chlorophyll content, (Suzuki et al., 2012). Meanwhile, brassinosteriods (presented in $\mathrm{NB}_{1}$ ) increased chlorophyll, this may be alleviate the negative effect of low temperature and chilling stress by increasing chlorophyll content which inducing changed in defense enzymes. In addition (Nimbolkar et al., 2016) cited that spraying pear plants by CPPU (presented in $\mathrm{NB}_{1}$ ) at $5 \mathrm{ppm}$ increased chlorophyll a and $b$.
JA application protect the membranes from damage and subsequently protect chloroplast membrane which increase chlorophyll content (Sorial Mervat et al. 2010 and El-Shraiy Amal and Hegazi 2010). Also, Hanaka et al. (2015) mentioned that the protective role of MJ treated phaseolus coccines plants have significant improvement in chlorophyll pigments.

Moreover, Sonali Jana and Jeong (2014) proved that foliar spray of silicon has been shown to enhance plant metabolism and leaf chlorophyll content and mitigate nutrient imbalance in plants.

\subsection{Antioxidant Enzymes:}

Data recorded in (Table, 3 ) showed the changes in antioxidant enzymes (polyphenoloxidase (PPO), peroxidase (PO) and catalase (CAT) enzymes). In chilled stress plants PPO activity, was lowered as compared to the sprayed plants by nanobiostimulatores. Foliar application of $\mathrm{NB}_{1}$ under chilling stress condition resulted in significant increase in enzyme activity, in both seasons. $\mathrm{Si}_{1,2}$ treatments under chilling stress followed the $N_{1}$ in enhancing significantly PPO activity in both season .

Regarding to PO activity, it can be noticed that the same trend recorded in PPO. There was a significant increase in PO activity with $\mathrm{NB}_{1}$ and $\mathrm{Si}_{1}$ treatments were by $132 \%$, and $51 \%$ when compared to chilled plants in the first season. The same trend was observed in the second season.

In this respect, CAT enzyme activity recorded the lowest value in plants under chilling stress compared to the treated plants with nanobiostimulators materials under chilling stress, data presented in (Table, 3). The values of CAT enzyme was highly significant increased by $\mathrm{NB}_{1}$ followed by $\mathrm{Si}_{1}$. The increases were by $116 \%$, and $39 \%$ compared to chilled 
A. A. Midan, et al.,

\begin{tabular}{|c|c|c|c|c|c|c|c|c|c|}
\hline 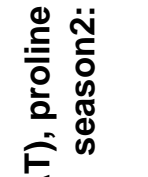 & 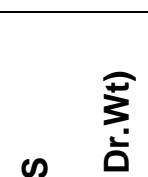 & 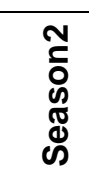 & 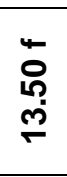 & $\begin{array}{l}\pi \\
0 \\
0 \\
\infty\end{array}$ & $\begin{array}{l}\text { 음 } \\
\frac{0}{+} \\
\dot{T}\end{array}$ & $\begin{array}{l}0 \\
\stackrel{+}{\infty} \\
\stackrel{\Gamma}{\oplus}\end{array}$ & $\begin{array}{l}0 \\
\dddot{m} \\
\infty \\
\dot{T}\end{array}$ & 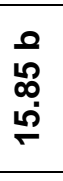 & $\begin{array}{l}0 \\
\infty \\
\dot{I}\end{array}$ \\
\hline 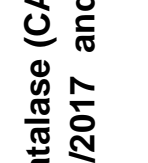 & • हे है & 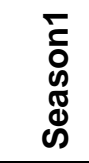 & $\begin{array}{l}\stackrel{0}{0} \\
\frac{n}{9}\end{array}$ & 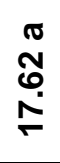 & 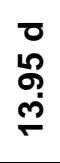 & $\begin{array}{l}0 \\
\frac{\infty}{\infty} \\
\dot{m}\end{array}$ & $\begin{array}{l}\frac{0}{N} \\
\stackrel{+}{ \pm}\end{array}$ & 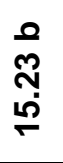 & $\begin{array}{l}0 \\
i n \\
\dot{10}\end{array}$ \\
\hline 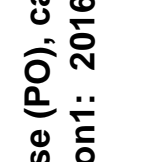 & 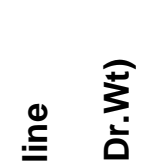 & 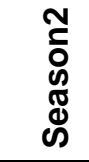 & $\begin{array}{l}0 \\
\substack{n \\
6}\end{array}$ & $\begin{array}{l}\tilde{\sigma} \\
\stackrel{R}{\Gamma}\end{array}$ & $\begin{array}{l}\text { 응 } \\
\text { டூ }\end{array}$ & స్ & $\frac{0}{\text { สু }}$ & $\begin{array}{l}0 \\
\stackrel{0}{9} \\
\stackrel{9}{+}\end{array}$ & 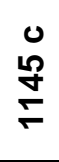 \\
\hline 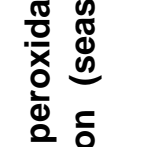 & 음 올 & 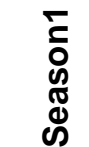 & ণ্ & $\begin{array}{l}0 \\
\dddot{0} \\
\stackrel{0}{0}\end{array}$ & $\begin{array}{l}\text { ర } \\
\text { గొ } \\
\infty\end{array}$ & $\overleftarrow{E}$ & $\frac{0}{6}$ & 怘 & $\begin{array}{l}0 \\
\stackrel{0}{\infty} \\
\stackrel{\infty}{\infty}\end{array}$ \\
\hline 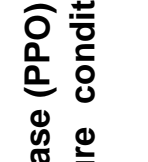 & 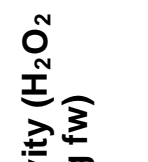 & 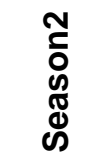 & t্ট & 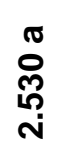 & $\stackrel{0}{\frac{0}{n}}$ & 욤 & $\begin{array}{l}0 \\
0 \\
\stackrel{+}{N} \\
\end{array}$ & 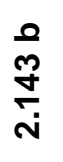 & $\begin{array}{l}0 \\
\text { !n } \\
\stackrel{0}{0}\end{array}$ \\
\hline 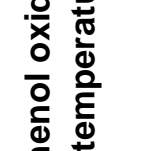 & 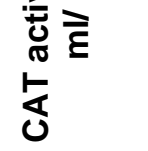 & 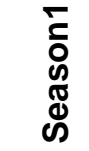 & ஸ్ & 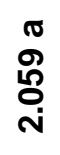 & $\begin{array}{l}0 \\
8 \\
\\
\end{array}$ & $\begin{array}{l}0 \\
\stackrel{0}{0} \\
\frac{1}{\sigma}\end{array}$ & $\begin{array}{l}0 \\
\mathscr{g} \\
\stackrel{2}{-}\end{array}$ & $\begin{array}{l}\stackrel{0}{\hat{N}} \\
\stackrel{\text { }}{-}\end{array}$ & 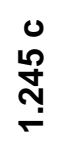 \\
\hline 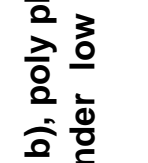 & 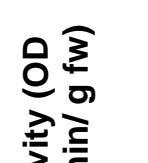 & 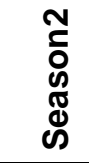 & $\begin{array}{l}0 \\
0 \\
0 \\
0 \\
\end{array}$ & 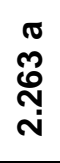 & $\stackrel{0}{\stackrel{0}{N}}$ & ণ্ণ & 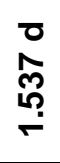 & $\stackrel{0}{N}$ & 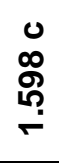 \\
\hline 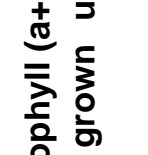 & 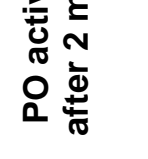 & 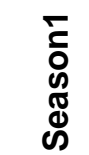 & ড్ & $\begin{array}{l}\infty \\
\infty \\
m \\
\\
i\end{array}$ & 옹 & $\begin{array}{l}0 \\
\stackrel{0}{0} \\
\stackrel{9}{0} \\
0\end{array}$ & 品 & 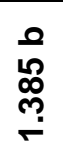 & $\begin{array}{l}0 \\
\text { ָे } \\
\text { ִָ }\end{array}$ \\
\hline 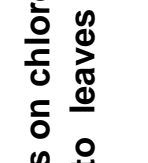 & 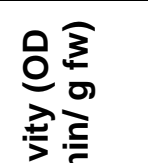 & 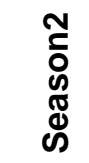 & $\begin{array}{l}\text { ס } \\
\stackrel{0}{\circ} \\
\stackrel{9}{+}\end{array}$ & $\begin{array}{l}0 \\
8 \\
0 \\
0 \\
0\end{array}$ & $\begin{array}{l}0 \\
\stackrel{\text { }}{\text { m }} \\
\text { n }\end{array}$ & 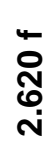 & $\begin{array}{l}0 \\
8 \\
8 \\
+\end{array}$ & $\begin{array}{l}\circ \\
\stackrel{0}{0} \\
\stackrel{0}{0} \\
\text { in }\end{array}$ & $\begin{array}{l}0 \\
\text { in } \\
\frac{1}{10}\end{array}$ \\
\hline 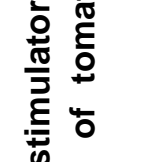 & 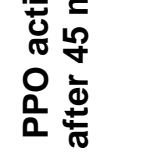 & 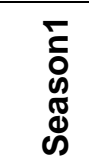 & ড্ষ্ণ & $\begin{array}{l}0 \\
8 \\
10 \\
\dot{+}\end{array}$ & 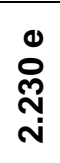 & $\frac{0}{\stackrel{0}{R}}$ & 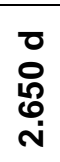 & 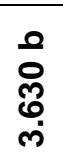 & $\frac{0}{\stackrel{0}{R}}$ \\
\hline 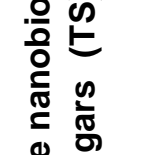 & 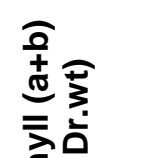 & 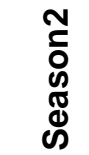 & 亡ू & $\frac{\pi}{\pi}$ & $\begin{array}{l}\text { D } \\
\text { மn } \\
\text { in }\end{array}$ & $\stackrel{0}{\sigma}$ & 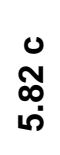 & 욜 & $\frac{0}{6}$ \\
\hline 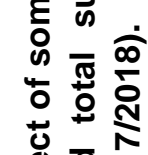 & 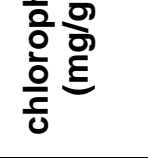 & 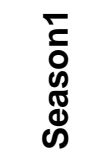 & 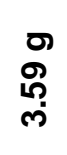 & 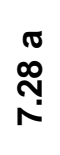 & $\begin{array}{l}0 \\
\stackrel{+}{+} \\
\dot{\forall}\end{array}$ & $\frac{\grave{\sigma}}{\dot{\sigma}}$ & 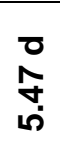 & $\frac{0}{\frac{m}{0}}$ & $\begin{array}{l}0 \\
\infty \\
\infty \\
0 \\
1\end{array}$ \\
\hline 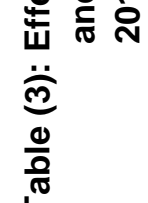 & & 象 & రั) & $\mathbf{m}$ & $\underline{\mathbf{m}}$ & $\Delta$ & 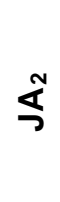 & $\bar{\omega}$ & $\bar{\omega}$ \\
\hline
\end{tabular}


plants, respectively in the first season. The same trend was observed in the second season. In this concern, Yildiztugay et al. (2017) reported that low temperature (5 c) stress caused an increase in activities of ascorbate peroxidase, glutathione reductase and NADP oxidase. Meanwhile, Rivero Rosa et al. (2001) cited that chilling stress occurred a lower peroxidase and poly phenol oxidase activity. Moreover, Sharma (2016) mentioned that BR increased the antioxidant enzyme activities indicating efficient scavenging of ROS in stressed tomato plants. Zhang et al. (2008) indicated that BR treatment promoted the activity of enzymes. He et al. (2010) and Liang et al. (2008) reported that the protective role of $\mathrm{Si}$ in plants exposed to cold stress conditions in many plants and this may due to increase the antioxidant activity in winter wheat and cucumber leaves. It is long lived and capable of crossing plant cell membranes and there by acts as diffusible and relatively last signal. $\mathrm{H}_{2} \mathrm{O}_{2}$ has been considered as an essential signal involved in plant defense against biotic and abiotic stresses (Foyer and Noctor 2003). Data of this experiment clearly indicate that nanobiostimulatores under studying protect antioxidant enzymes and to guard protein and nitrogen content along with rubisco activity for recovering photosynthetic rate under stress (Sadia Sadique, 2017).

\subsection{Proline content:}

The data in (Table, 3) revealed that proline content increased under chilling conditions. Moreover, treatments with different nanobiostimulators recorded highly significant increases in proline content under chilling conditions. The most effective treatment in increasing proline content was $\mathrm{NB}_{1}$ then $\mathrm{Si}_{1}$ and $\mathbf{S i}_{2}$ when compared to the chilled plants. Proline content was increased by $355 \%$, $235 \%$ and $121 \%$ compared to the chilled tomato plants only, respectively in the first seasons. The same trend was observed in the second season. Moreover, the other nanobiostimulators materials i.e $\mathbf{N B}_{2}, \mathrm{JA}_{1}$ and $\mathrm{JA}_{2}$ also recorded a significant increase in proline content compared with the chilled plants, in both seasons. Many studies have provided that the exogenous application of proline (presented in $\mathbf{N B}_{1}, \mathbf{N B}_{2}$ ) provided better protection against different abiotic stresses such as salinity, drought and extreme temperature, etc. Under these stressful environmental conditions, exogenous applications of proline have been shown to increase the endogenous levels of proline and compatible solute which provide protection to cells through osmotic adjustment, in addition help to maintain cellular ionic homeostasis. Moreover, exogenous application of proline at low concentration increased tolerance towards cold stress (Hayat et al., 2012). In the present study, Brassinolides treatment (presented in $\mathrm{NB}_{1}$ ) obviously improved significant increase in proline resulted osmotic adjustment to a great extant.

Mitigation of oxidative stress by $\mathrm{Si}$ treatments has been related to accumulation of antioxidants (phenolics, proline and ascorbic acid) that under low temperature stress in wheat (Liang et al., 2008) and cucumber (Moradtalab Narges et al., 2018). Review of literature indicated that stressful environment result in an over production of proline in plants which increase stress tolerance by maintaining osmotic balance, stabilizing membranes thereby preventing electrolyte leakage and bringing (ROS) within normal ranges thus preventing oxidative burst in plants (Hayat et al., 2012).

\subsection{Total sugars:}

Data revealed that chilling conditions enhanced accumulation of total soluble 
sugars (Table, 3 ). Moreover application of $\mathrm{NB}_{1}$, and $\mathrm{Si}_{1,2}$, treatments under chilling conditions significantly increased total soluble sugars which increased by $34 \%$, $16 \%$ and $10 \%$ when compared to the chilled plants only in the first season, meanwhile, were $39 \%, 17 \%$ and $9 \%$ in the second season, respectively.

Sugars play a control regulatory role in many vital processes of photosynthetic plants besides saving the energetic function and considered as important signals that regulate plant metabolism and development. Carbohydrate accumulation at low temperature may explained through the activation and enhanced expression of the enzymes involved in the sucrose synthesis pathways and those of Calvin cycle in particular, the cytosolic enzymes (Couee et al., 2006). Moreover they might protect plant cell membranes during cold. Induced dehydration, replacing water species and by acting as hydroxyl scavengers and so, increased membrane stabilization (Couee et al., 2006 and Ruelland et al., 2009).

Resulted of current study (Table,3) showed that the low concentration of $\mathrm{NB}_{1}$ and $\mathrm{NB}_{2}$ increased significantly soluble sugars of tomato plants grown under chilling condition compared to their respective untreated plants. Treatment with $\mathrm{NB}_{1}$ which contains CPPU, Brassinolide and Proline, increased significantly total sugars of chilled leaves. It is mentioned that the positive effects of CPPU at $20 \mathrm{ppm}$ was correlated with significant increase in total soluble sugars in potato leaves (El-shraiy Amal and Hegazi, 2010). Moreover Sorial Mervat et al. (2010) cited that exogenous JA application generally decreased total soluble sugars compared to untreated plants. (Liang et al., 2008 and Moradtalab Narges et al., 2018) reported the protective role of $\mathrm{Si}$ in plants exposed to cold stress conditions in many plants, the mechanism of $\mathrm{Si}$ in promoting the accumulation of sucrose in leaves (Neethirajan et al., 2009).

\section{Yield and its components:}

It is also observed that treatments considerably differed among of these in their effects since great enhanced fruits set $\%$, was obtained by $\mathrm{NB}_{1}$ followed by $\mathrm{NB}_{2}$, while the increases by, $\mathrm{NB}_{1}$ was $(78 \%)$ and $(83 \%)$ compared to their control chilled plants only in the first and the second seasons, respectively. In this respect it was clear that $\mathrm{Si}_{1}$ also enhanced the fruits set \%, parameter followed by $\mathrm{Si}_{2}$ and then $\mathrm{JA}_{2}$ compared to the chilled plants (Table 4 and Fig., 2).

It is quite clear from (Table 4 and Fig., 2) that early and total yield per feddan were significantly increased as the results of all applied treatments under studying compared with the chilled tomato plants only, in both seasons. On the contrary, the chilled plants (control) plants were strongly stressed. It is also observed that treatments considerably differed among of their effects since great enhanced early and total yield per feddan were obtained by $\mathrm{NB}_{1}$, while the increase were by $48 \%$ and $37 \%$, where were $40 \%$, and $28 \%$ for $\mathrm{Si}_{1}$ compared to their control chilled plants only in the second season, respectively. The same trend was observed in the first season. In this respect, it was clear that $\mathrm{Si}_{1}$ also enhanced the above parameters followed by $\mathrm{Si}_{2}$ and $\mathrm{JA}_{2}$ compared to the chilled plants.

The explanation of yield increases of stressed, plants after application of proline (present in $\mathrm{NB}_{1}, \mathrm{NB}_{2}$ ) has been proposed to the partly located on the increased net photosynthesis, decreased rate of photorespiration, conductance, induced more efficient gas exchange (Makela et al., 1998) and thus better availability of carbon for photosynthetic processes (Makela et al., 1999), water use efficiency (Bergmann and Eckert 1984) 
Effect of some nanobiostimulators to alleviate the adverse effects of chilling ....

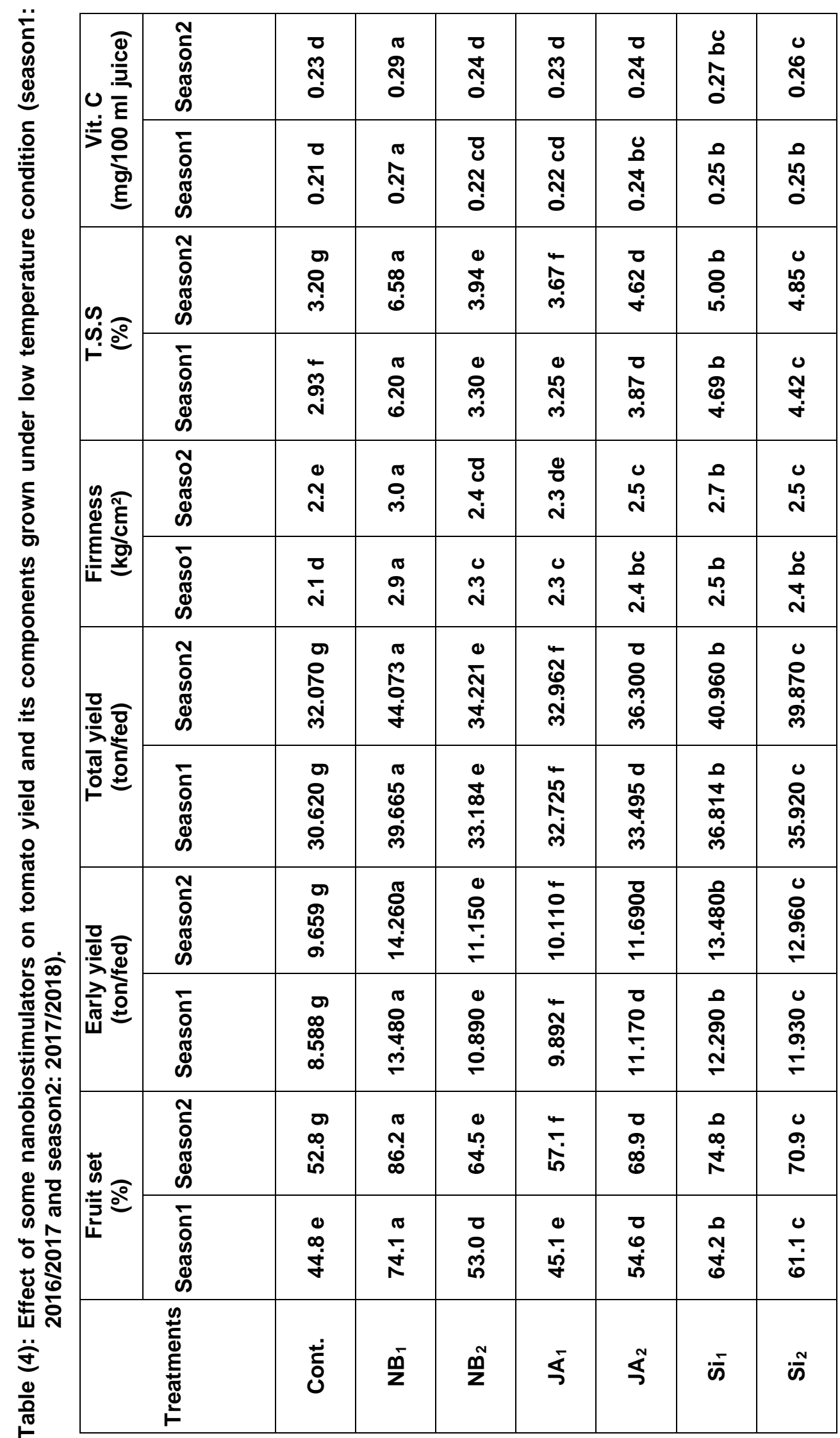


A. A. Midan, et al.,

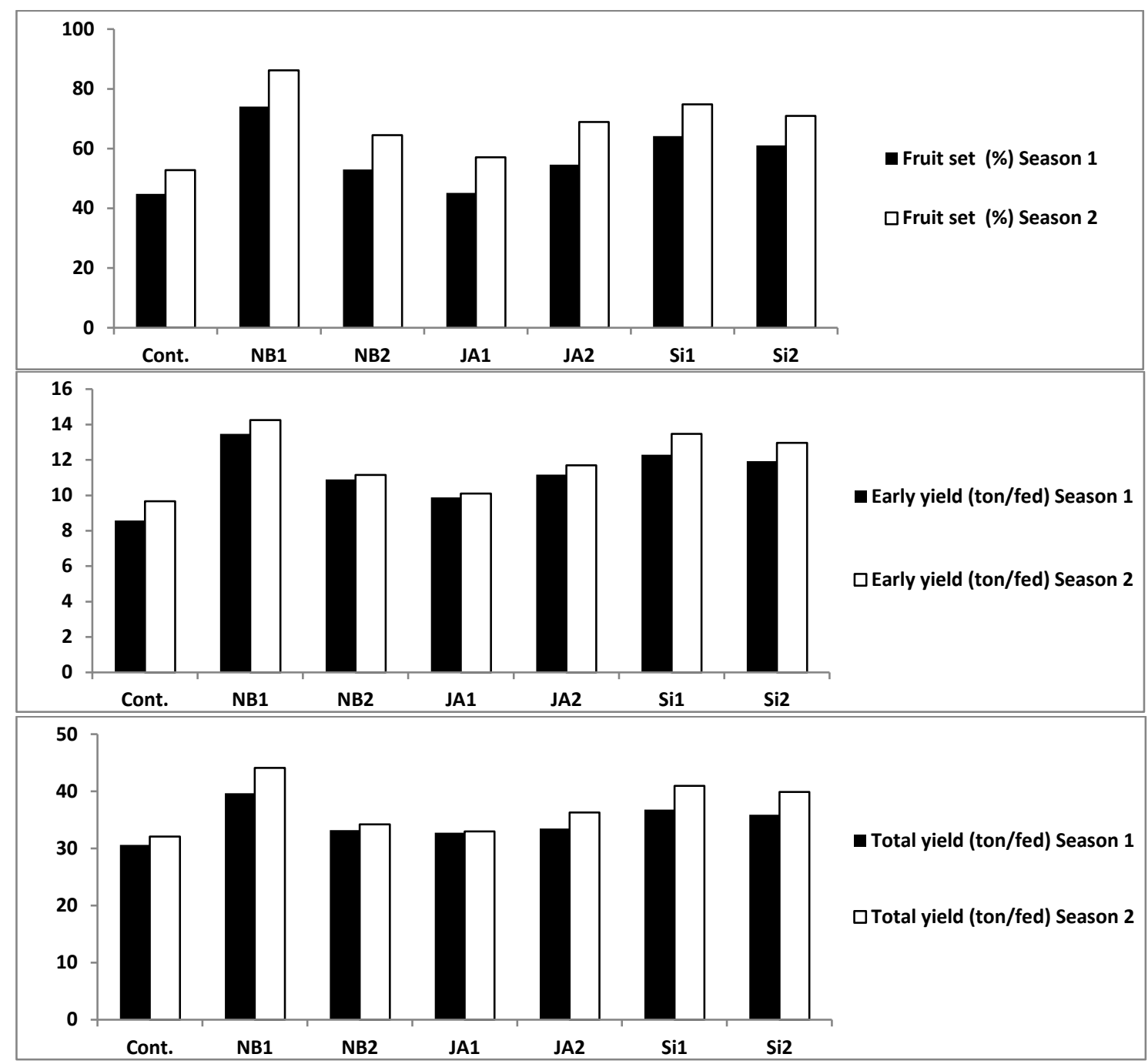

Figures (2): Effect of some nanobiostimulators on fruit set and tomato early yield and total yield grown under low temperature condition (season1: 2016/2017 and season2: 2017/2018).

and increased chlorophyll content in plants (Whapman et al., 1993). Moreover proline protects and activates the proteins of photosynthetic reactions (Papageorgiou and Murata, 1995). Exogenous application of proline also results in higher yield in the greenhouse and field, mainly due to improved net photosynthesis and growth rate (Makela et al., 1998 and Rezaei et al., 2012).

The high fruit set percentage as well as early and total yield might be owing to the optimum application of CPPU with Brassinolide (presented in $\mathrm{NB}_{1}$ ) and $\mathrm{Si}$ as a foliar feeding, the obtained results are in conformity with those previously reported by (Kabeel et al., 2005 and Guirguis et al., 2003). Moreover Epstein (1999) proved that, maintenance of leaves as a result of silicate application, which increase in the photosynthesis of the canopy and consequently increases in growth and yield. Ismail et al. (2014) stated that silicon supply improved the structural integrity of crops and promoted the increase of water relation in leaf tissue which a result of higher growth rate under stress conditions. 
The increasing in tomato fruit size as a result of CPPU application is due to the increase in sink strength for accumulating nutrients such as $K$, this data agreement with the finding in berry by (Zhenming et al., 2008). Moreovere, application of BR gave positive effect in cluster weight may be due to beneficial effect on increasing cell division and cell elongation as well as their great role in activating the biosynthesis of proteins (Fawzi and Hafez, 2004). These results are in agreement with those (Luan et al., 2013) regarding the potential role for brassinolide growth regulators as a fruit production management especially considering the results obtained regarding berry coloration. Moreover, Han and Lee (2004) demonstrated that using cytokinins in the vineyard was found to be effective in increasing berry size, pedicel thickness, and the amount of cuticle, delaying maturity, reducing anthocyanin content, and enhancing firmness.

It can observe in the present results in (Table 4 and Fig., 2) that the fruit quality like Firmness, TSS and Vit. C. It can be observed that the highest and significant values were recorded by application of $\mathrm{NB}_{1}$, which recorded $38 \%, 112 \%$ and $29 \%$ compared to the control (chilled plants) respectively in the first season, and $36 \%$, $105 \%$ and $26 \%$ in the second one. Moreover, $\mathrm{Si}_{1}$ was significantly enhanced the above mentioned parameters which were by $19 \%, 60 \%$ and $19 \%$ when compared to the control plants, respectively in the second season. Meanwhile $\mathrm{JA}_{2}$ significantly increased Firmness by $15 \%$, TSS by $44 \%$ and Vit. C by $4 \%$ when compared to their control fruits in the second season. The same trend was recorded in the first season.

Mousawinejad (2014) showed that, CPPU (presented inNB 1 ) application on tomato plants had highly significant increases on fruit mass, volume density, Length and width. Moreover, the effects of
CPPU on the fruit biochemical characteristics such as sugars, titratable acids and vitamin $C$ content were not significant some studies have proven the efficacy of CPPU as a PGR to improve the fruit development some seedless and seeded grape cultivars in field conditions. For example, in a study conducted by Nimbolkar et al. (2016), they showed that CPPU resulted in a significant increase in the mass and size of berry and cluster.

Lolaei et al. (2013) reported that straw berries treated with MJ had higher soluble solids content. Moreover the effect of MJ was significant the yield and growth of strawberry plants. Lu Maria et al. (2016) proved that $\mathrm{Si}$ supplementation using nanosilica powder is the most effective in improving the growth characteristics and yield of tomato. In addition, only nanosilicon significantly increased the average fruit yield of tomato by $35 \%$ as affected by the $23 \%$ increase in the average number of fruit per plant.

It can be concluded that, the observed results may show that tomato plants subjected to chilling stress recorded highly significant reduction in their growth and production parameters. Application of nanobiostimulators like $\mathrm{NB}_{1}$ (which contains BR, CPPU, Proline) and silicon which exerted the most protecting effect in alleviation of chilling injury with low concentration which reflect a good performance of tomato plants under chilling with high quantity and good quality of yield. Nanoparticles significantly increase plant dry weight, level of organic compounds such as proteins, chlorophyll, sugars and phenols. Silicon nanoparticles have unique physicochemical attributes and they enter into plants and impact the metabolism of plants, like wise improve plant growth and yield under pressure environmental conditions. Nanofertilizers could soon offer a technological solution to the nutrient-loss problem, thereby 
aiding technologically-minded farmers and subsistence farming. Nanofertilizers refer to nanoscale-dimension products that deliver nutrients to crops. These nutrients can be i) encased inside nanomaterials for example nanotubes or nanoporous materials, ii) covered with a thin defensive polymer film, or iii) conveyed as particles or emulsions (Sadique Sadia,2017).

\section{REFERENCES}

A.O.A.C. (1980). Official Methods of Analysis. 18th ed. Association of Official Agricultural Chemists, Washington, DC, USA.

Abd-Allah, E.F., A.A. Alqarawi, Sarah A. Al-rashed, Abeer Hashem, Asma A. Alhuqail and Norah S. Aldosari (2016). Modulation of adverse impact of chilling in vica faba L. By methyl jasmonate involves changes in 2016antioxidant metabolism and metabolites. Pak. J. Bot., 48(5): 19151923.

Ahmed, F.A. and A.M.K. Abdel-aal (2007). Effect of concentration of spraying sitofex (CPPU) on yield and quality of Le-Conte pear fruits. Afr. Crop Sci. J., 8: 523-527.

Anwar, A., Y. Liu, R. Dong, L. Bai, X. Yu and Y. Li (2018). The physiological and molecular mechanism of brassinosteroid in response to stress: a review. Biol. Res., 51:1-15.

Bach A.N. and Oparin, A.E. (1968).Research methods in bacterial causes of plants, pp.184-187.

Bates, L., R.P. Waldren and I.D. Teare (1973). Rapid determination of free proline for water-stress studies. Plant and Soil, 39: 205-207.

Bergmann, H. and H. Eckert (1984). Einfluss von Glycinbetain auf die Wasserausnutzung von Winterweizen Triticum aesti6um L. Biol. Plant, 26: 384-387.
Broesch, S. (1954). Colormetric assay of phenol oxidase, Bull. Sac. Chem. Biol., 36: 711-713.

CoStat software (1985). User's Manual. Version 3, Co. Hort. Tusson. Arizona U.S.A

Couee, I., C. Sulmon, G. Gouesbet and A. El-Amrani (2006). Involvement of soluble sugars in reactive oxygen species balance and responses to oxidative stress in plants. J. Exp. Bot., 57:449-459.

Creelman, R. A. and J. E. Mullet (1997). Biosynthesis and action of jasmonates in plants. Annu. Rev. Plant Physiol. Plant Mol. Biol. 48, 355-381.

Ding, C.K., C.Y. Wang, K.C. Gross and D.L. Smith (2001). Reduction of chilling injury and transcript accumulation of heat shock proteins in tomato fruit by methyl jasmonate and methyl salicylate. Plant Sci., 161: 1153-1159.

Dubois, M., K.A. Gilles, J.K. Hamilton, P.A. Rebers and F. Smith (1956). Colorimetric method for determination of sugars and related substances. Analytical chemistry, 23(3): 350-356.

El-Shraiy, Amal M. and Amira M. Hegazi (2010). Influence of JA and CPPU on Growth, Yield and á- Amylase Activity in Potato Plant (Solanum tuberosum L.). Australian Journal of Basic and Applied Sciences, 4(2): 160-170.

Epstein, E. (1999). Silicon. Ann. Rev. Plant Phys. \& Plant Molecular Biol., 50: 439448.

Fawzi, M.I.F. and O.M. Hafez (2004). Effect of some growth regulators on yield and fruit quality of perlette grapes. Annals Agric. Sci., Ain Shams Univ., Cairo, 49 (2): 671-686.

Fehrman, H. and A.E. Dimond (1967). Peroxidase activity and Phytophtora resistance in different organs of the potato. Plant Pathology 57: 69-72.

Foyer, C.H. and G. Noctor (2003). Redox sensing and signalling associated withreactive oxygen in chloroplasts, 
peroxisomes and mitochondria. Physiol. Plant, 119: 355-364.

González-Aguilar, G.A., J. Fortiz, R. Cruz, R. Baez and C.Y. Wang (2000). Methyl Jasmonate Reduces Chilling Injury and Maintains Postharvest Quality of Mango Fruit. J. Agric. Food Chem., 48: 515-519.

González-Aguilar, G.A., M. TiznadoHernández and C.Y. Wang (2006). Physiological and Biochemical responses of Horticultural Products to Methyl Jasmonate. Stewart Postharvest Review. 2(1):1-9.

Graham, D. and B.D. Patterson (1982). Response of plants to low, nanfreezing temperatures: Proteins, metabolism and acclimation. Ann. Rev. Plant Physiol., 33:347-372.

Guirguis, N.S., E.S. Attala and M.M. Aly (2003). Effect of sitofex (CPPU) on fruit set and fruit quality of "Le-Conte" pear cultivar. Annals of Agric. Sci. Moshtohor, 41 (1): 271-282.

Guo, W., Y.G. Zhu, W.J. Liu, Y.C. Liang, C.N. Geng and S.G. Wang (2007). Is the effect of silicon on rice uptake of arsenate related to internal silicon concentrations, iron plaque and phosphate nutrition? Environ Pollut, 148: 251-257.

Han, D.H. and C.H. Lee (2004). The effects of GA3, CPPU and ABA applications on the quality of Kyoho (Vitis vinifera $L$. $x$ Labrusca L.) grape. Acta. Hortic., 653: 193-197.

Hanaka, A., W. Maksymiec and W. Bednarek (2015). The effect of methyl jasmonate on selected physiological parameters of copper-treated Phaseolus coccineus plants. Plant Growth Regul, 77:167-177.

Hayat, S., Q. Hayat, M.S. Alyemeni, A.S. Wani, J. Pichtel and A. Ahmad (2012). Role of proline under changing environments. Plant Signal Behav., 7: 1456-1466.

He, Y., H. Xiao, H. Wang, Y. Chen and M. Yu (2010). Effect of silicon on chilling- induced changes of solutes, antioxidants, and membrane stability in seashore paspalum turfgrass. Acta Physiol. Plant, 32:487-494.

Hussain, H.A., S. Hussain, A. Khaliq, U. Ashraf, S.A. Anjum, S.N. Men and L. Wang (2018). Chilling and drought stresses in crop plants: Implications, cross talk, and potential management opportunities. Front. Plant Sci., 10 (9): 393.

Ismail, E.A., S.M. Hussien and Abou Fatma I. Grah (2014). Studies on Improving Fruit Yield and Quality of Peach CV. "Early sweeling". Egypt J. Hort., 41(1): $83-95$.

Kabeel, H., S.A.A. Fawaaz and F.A. Kh. Sabek (2005). Effect of spraying potassium and calcium at different concentrations on leaf nutrient status, yield and fruit characteristics of "Costata" persimmon trees. Res. Jour. Soc. En. Sci., 3 (3): 216-235.

Kerdaimongko, K., A. Bhatia, R.J. Joly and W.R. Woodson (1997). Oxidative stress and diurnal variation in chilling sensitivity of tomato seedling. J. Amer. Soc. Hort. Sci., 122(4): 485-490.

Levitt, J. (1980). Responses of plant to environmental stresses. Chilling. Freezing and high temperature stresses. New York, Academic, pp. 497.

Li J., P. Yang, J. Kang, Y. Gan, J. Yu, A. Calderón-Urrea, L. Jian, Zhang G., Feng Z. and J. Xie (2016). Transcriptome analysis of pepper revealed a role of 24-epibrassinolide in response to chilling. Front Plant Sci., 7: 1-16.

Li, P., L. Chen, Y. Zhou, X. Xia, K. Shi, Z. Chen and J. Yu (2013). Brassinosteroids-induced systemic stress tolerance was associated with increased transcripts of several defence-related genes in the phloem in Cucumis sativus L. PLoS ONE. 8(6): 566-582.

Liang, Y., J. Zhuc, Z. Li, G. Chua, Y. Dingc, J. Zhangc and W. Sun (2008). Role of Si 
in enhancing resistance to freezing stress in two contrasting winter wheat cultivars. Environ. Exp. Bot., 64: 286294.

Lolaei, A., N. Teymouri, R. K. Bemana, pour A. K. and S. Aminian (2013). Effect of gibberellin on vegetative and sexual growth and fruit quality of strawberry (Fragaria $\times$ Ananassa Duch. cv. Selva and Qeenelisa), Intl. J. Agric. Crop Sci., 5 (14): 1508-1513.

Lu, Maria M. D., Diana M.R. De Silva, Engelbert K. Peralta, Alvin N. Fajardo and Milagros M. Peralta (2016). Growth and yield of tomato applied with silicon supplements with varying material structures. Philippine e-Journal for Applied Research and Development, 6:10-18.

Luan, L.Y., Z.W. Zhang, Z.M. Xi, S.S. Huo and L.N. Ma (2013). Brassinosteroids regulate anthocyanin biosynthesis in the ripening of grape berries. S. Afr. J. Enol. Vitic., 34: 196-203.

Ma, G.X., J. Lee, Y. Deng and A. Kolmakov (2010). Interaction between engineered nano particles (ENPS) and plants phytotoxicity, uptake and accumulation. Sci. Total Environ.4008 (16): 3053-3061.

Makela, P., M. Kontturi, E. Pehu and S. Somersalo (1999). Photosynthetic response of drought- and saltstressed tomato and turnip rape plants to foliarapplied glycine betaine. Phys. Plantarum, 105: 45-50.

Makela, P., R. Munns, T.D. Colmer, A.G. Cundon and P. Peltonen-Sainio (1998). Effect of foliar applications of glycine betaine on stomatal conductance, abscisic acid and solute concentrations of salt and drought stressed tomato. Aust. J. Plant Physiol., 25: 655-663.

Mirdehghan, S.H. and F. Ghotbi (2014). Effects of Salicylic Acid, Jasmonic Acid and Calcium Chloride on Reducing Chilling Injury of
Pomegranate (Punica granatum L.) Fruit. J. Agric. Sci. Tech., 16:163-173.

Mo, Z.W., U. Ashraf, S.G. Pan, A.S. Kanu, W. Li, M.Y. Duan, H. Tian and X.R. Tang (2016). Exogenous application of plant growth regulators induce chilling tolerance in direct seeded super and non-super rice seedlings through modulations in morpho-physiological attributes. Cereal Research Communications, 44(3): 524-534.

Mok, D.W.S and M.C. Mok (2001). Cytokinin metabolism and action. Annu. Rev. Plant. Biol., 52: 89-118.

Moradtalab Narges, M. Weinmann, F. Walker, B. Höglinger, U. Ludewig and G. Neumann (2018). Silicon Improves Chilling Tolerance During Early Growth of Maize by Effects on Micronutrient Homeostasis and Hormonal Balances. Plant Science, 9:420.

Mousawinejad, S., F.N. Nahandi and A. Baghalzadeh (2014). Effects of CPPU on size and quality of tomato (Solanum lycopersicum L.) fruits. Intl J Farm \& Alli Sci. 3 (8): 930-934.

Neethirajan, S., R. Gordon and L. Wang (2009). Potential of silica bodies (phytoliths) for nanotechnology. Trends in Biotechnology, 27: 461:467.

Nimbolkar, P.K., P.N. Rai, Mishra, S.K. Singh, A.K. Singh and J. Kumar (2016). Effect of CPPU, NAA and Salicylic Acid on Vegetative Growth, Fruit Retention and Yield of Pear [Pyrus pyrifolia (Burm.) Nakai] cv Gola. Environment \& Ecology, 34 (2): 462-465.

Papageorgiou, G.C. and N. Murata (1995). The unusually strong stabilizing effects of glycine betaine on the structure and function of the oxygenevolving photosystem II complex. Photosynthesis Res., 44: 243-252.

Prasad, T.K., M.D. Anderson, B.A. Martin and C.R. Stewart (1994). Evidence for chilling induced oxidative stress in maize seedlings and a regulatory role of hydrogen peroxide. Plant Cell, 6: 6574. 
Rejab, M., C.S. Teck, K.M. Zain and M. Muhamad (2008). Mangosteen. In Kwok CY, Lian TS, Jamaluddin SH, ed, Breeding Horticicultural Crops. MARDI: Kuala Lumpur, pp. 155-174.

Rezaei, M. A., I. Jokar, M. Ghorbanli, B. Kaviani and A. Kharabian-Masouleh (2012). Morphophysiological improving effects of exogenous glycine betaine on tomato (Lycopersicum esculentum Mill.) cv. PS under drought stress conditions Plant Omics J., 5(2):79- 86.

Rivero Rosa M., J.M. Ruiz, P.C. Garcı, L. R. Lopez-Lefebre, E. Sánchez and L. Romero (2001). Resistance to cold and heat stress: accumulation of phenolic compounds in tomato and watermelon plants. Plant Sci., 160 (2): 315-321.

Ruelland, E., M.N. Vaultier, A. Zachowski, V. Hurry, J.C. Kader and M. Delseny (2009). Cold signalling and cold acclimation in plants. Adv. Bot. Res., 49:35-150.

Ruiz-Lozano, J., R. Porcel, C. Azcón and R. Aroca (2012). Regulation by arbuscular mycorrhizae of the integrated physiological response to salinity in plants: new challenges in physiological and molecular studies. $J$. Exp. Bot., 63(11): 4033-4044.

Rymen, B., F. Fiorani, F. Kartal, K. Vandepoele, D. Inze and G.T.S. Beemster (2007). Cold nights impair leaf growth and cell cycle progression in maize through transcriptional changes of cell cycle genes. Plant Physiol., 143: 1429-1438.

Sadique, Sadia, Nisar Shafaq, R.M. Dharmadasa and M.I. Jilani (2017). Effect of nano-fertilizer and growth hormones on different plants. IJCBS, 11: 113-119

Sharma, N. (2016). Effect of brassinosteroid (brassinolide) on morpho-physiological, biochemical attributes and antioxidant enzyme activity in tomato (Lycopersicon esculentum L.) under drought stress. Ms Thesis, u.p., India, pp 1- 77.

Shu, S., Y. Tang, Y. Yuan, J. Sun, M. Zhong and S. Guo (2016). The role of 24epibrassinolide in the regulation of photosynthetic characteristics and nitrogen metabolism of tomato seedlings under a combined low temperature and weak light stress. Plant Physiol. Biochem., 107: 344-53.

Snedecor, W. and W.G. Cochran (1972). Statistical Method. 6th Edition. The lowa State College Press. lowa, U.S.A.

Solanke, A.U. and A.K. Sharma (2008). Signal transduction during cold stress in plants. Physiol. Mol. Biol. Plants, 14: 69-79.

Sonali Jana and B. R. Jeong (2014). Silicon: The Most Under-appreciated Element in Horticultural Crops. Trends in Horticultural Research, 4: 1-19.

Sorial, Mervat E., S.M. El Gamal and A.A. Gendy (2010). Response of sweet basil to jasmonic acid application in relation to different water supplies. Bio. sci. Res., 7 (1):39-47.

Suzuki, N., S. Koussevitzky, R. Mittler and G. Miller (2012). ROS and redox signaling in the response of plants to abiotic stress. Plant Cell Environ., 35: 259-270.

Thakur, P. and H. Nayyar (2013). Facing the cold stress in the changing environment: sensing, signaling and defending mechanisms. In (N. Tuteja N, Gill SS, ed, Plant Acclimation to Environmental Stress. New York, NY: Springer New York, pp. 29-70.

Wang, B. and G. Zeng (1993). Effect of epibrassinolide on the resistance of rice seedlings to chilling injury. Zhiwu Shengli Xuebao., 19: 53-60.

Wang, S.Y. (1999). Methyl jasmonate reduces water stress in strawberry. J. Plant Growth Regul., 18: 127-134.

Wettstein, D. (1957). Chlorophyll - letale und der submikroskopische Formwechsel der Plastiden. Exp. Cell Res., 12: 427-487. 
Whapman, C.A., G. Blunden, T. Jenkins and S.D. Hankins (1993). Significance of betaines in the increased chlorophyll content of plants treated with seaweed extract. J. Appl. Phycol., 5: 231-234.

Yildiztugay, E., C. Ozfidan-Konakci and M. Kucukoduk (2017). Improvement of cold stress resistance via free radical scavenging ability and promoted water status and photosynthetic capacity of gallic acid in soybean leaves. Journal of Soil Science and Plant Nutrition, 17: 366-384.

Yuan, L., S. Shu, J. Sun, S. Guo and T. Tezuka (2012). Effects of 24epibrassinolide on the photosynthetic characteristics, antioxidant system, and chloroplast ultrastructure in Cucumis sativus $\mathrm{L}$. under $\mathrm{Ca}(\mathrm{NO} 3) 2$ stress. Photosynth Res., 205: 14-112.

Zhang, M., Z. Zhai, X. Tian, L. Duan and Z. Li (2008). Brassinolide alleviated the adverse effect of water deficits on photosynthesis and the antioxidant of soybean (Glycine max L.). Plant Growth Regulation, 56(3): 257-264.

Zhenming, N., X. Xuefeng, W. Yi, L. Tianzhong, $K$. Jin and $H$. Zhenhai (2008). Effects of leaf applied potassium, Gibberellin and SourceSink Ratio on potassium absorption and distribution in grape fruits. Scientia Horticultural, 115: 164-167.

Ziosi, V., C. Bonghi, A.M. Bregoli, L. Trainotti, S. Biondi, S. Sutthiwal, S. Kondo, G. Costa and P. Torrigiani (2008). Jasmonateinducedtranscriptional changes suggest a negative interference with theripening syndrome in peach fruit. $J$. Exp. Bot., 59: 563-573.

Zouari, M., A. Ben Hassena, L. Trabelsi, B. Ben Rouina, R. Decou and P. Labrousse (2019). Exogenous proline mediated abiotic stress tolerance in plants possible mechanisms. In: osmoprotectant-mediated abiotic stress tolerance in plants. Springer, pp.99-121. 
تأثير بعض المنشطات النانو لتقليل الأثار الضاره للبرودة علي الطماطم

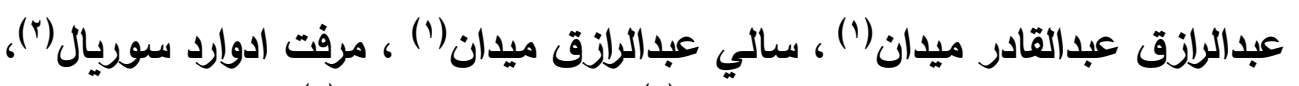

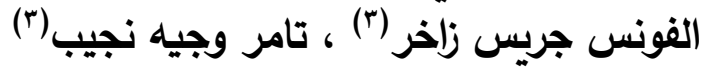

$$
\begin{aligned}
& \text { (1) (1) قسم البساتين- كلية الزراعة - جامعة المنوفية }
\end{aligned}
$$

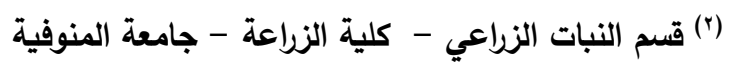

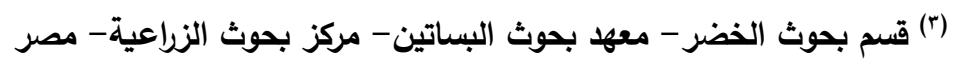

$$
\begin{aligned}
& \text { الملخص العربي }
\end{aligned}
$$

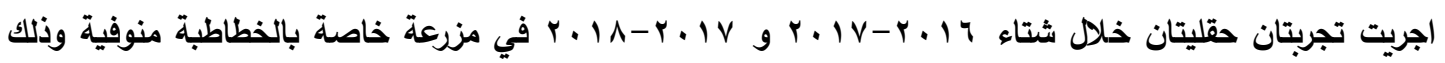

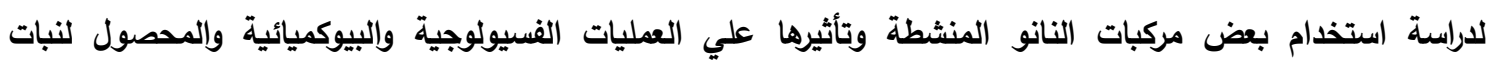

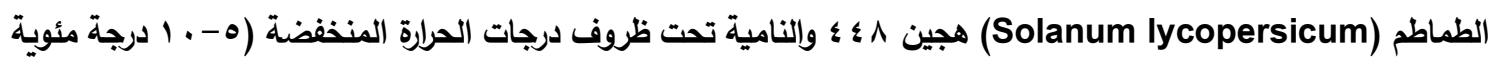

تم دراسة ؛ معاملات وهي (1) الكنترول: نباتات نامية تحت ظروف درجة الحرارة المنخفضة بدون اي معاملات خارجية.

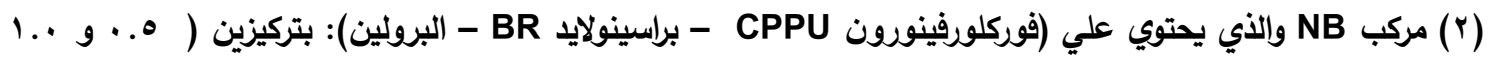

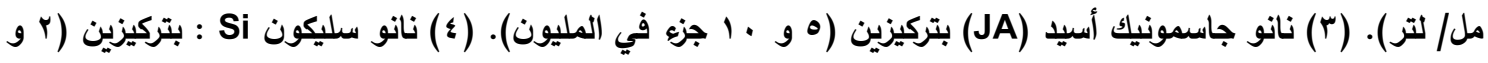

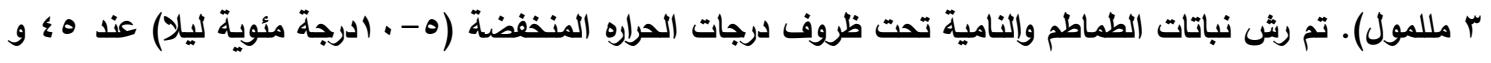

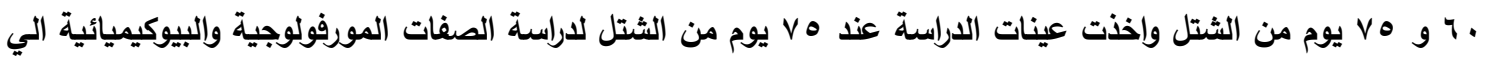

$$
\text { جانب المحصول من حيث الكمية وإلجودة. }
$$

وكان من أهم النتائج المتحصل عليها:

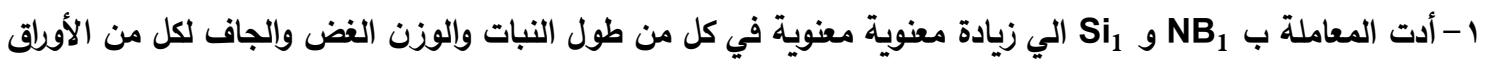

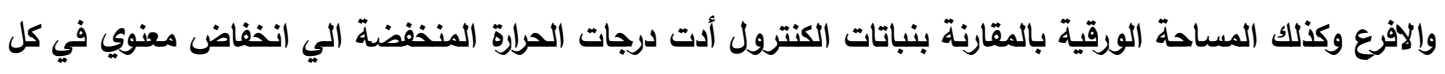

من طول النبات والوزن الغض والجاف لكل من الأوراق والافرع وكذلك المساحة الورقية.

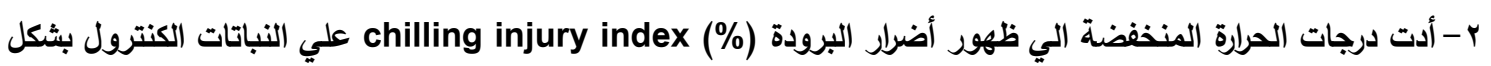

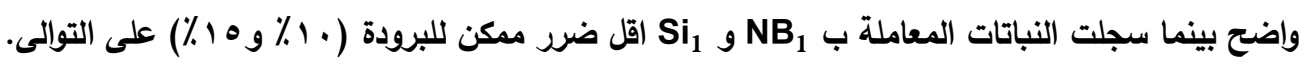

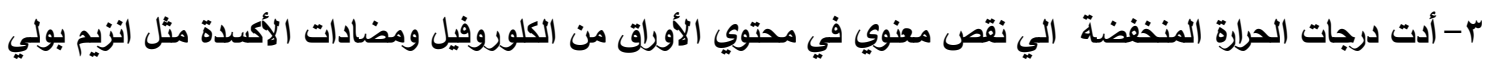

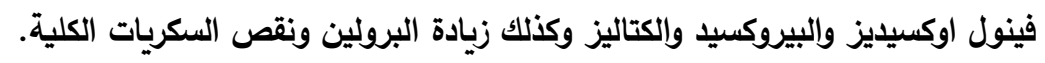

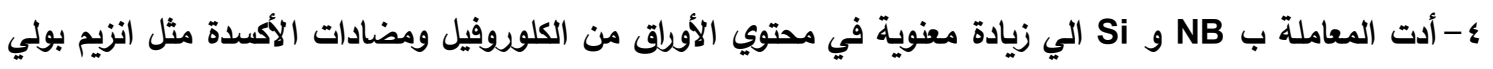
فينول اوكسيديز والبيروكسيد والكتاليز وكنلك زيادة البرولين والسكريات الكلية. ه - أدت المعاملات ب NB و Si بالتركيزات المنخفضة الي تحسن نمو النبات والمحصول المبكر والمحصول الكلي للطماطر بالمقارنه بالكنترول وكذلك زيادة معنوية في درجة الصلابة والمواد الصلبة الكلية و ل و لثمات لثمار الطماطم للنباتات النامية تحت ظروف درجات الحرارة المنخفضة. 


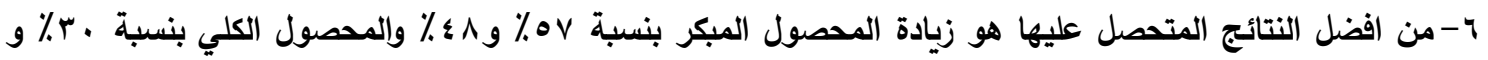

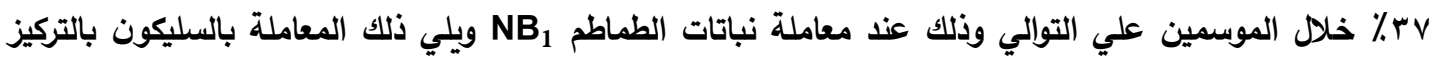

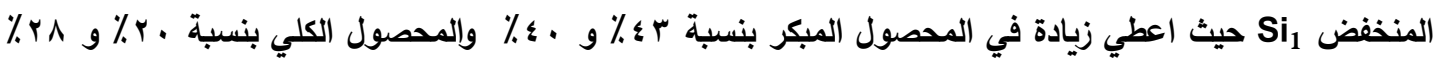
خلال الموسمين علي التوالي بالمقارنة بالكنترول.

التوصيه:

من هذه الاراسة يمكن التوصيه بأستخدام مركبات النانو التي تحتوي علي CPPU و BR والبرولين وكذلك السليكون وذلك بالتركيزات المنخفضة جدا حيث انعكس هذا علي نمو النبات وكمية المحصول وجودة الثمار. 